\title{
ANALISIS PENGADAAN INPUT PRODUKSI DAN SUBSISTEM USAHATANI PADI SAWAH DI DESA SAIK KECAMATAN KUANTAN MUDIK KABUPATEN KUANTAN SINGINGI
}

\section{Darus}

Dosen Jurusan Agribisnis Fakultas Pertanian Universitas Islam Riau

Abstrak

Ketersediaan bahan pangan yang dapat untuk mencukupi kebutuhan seluruh penduduk di suatu daerah menjadi perhatian Pemerintah, karena ketahanan pangan dapat menjaga stabilitas pada suatu daerah tersebut. Kabupaten Kuantan Singingi yang mempunyai potensi pertanian yang besar untuk dikembangkan, hal ini di dukung oleh ketersediaan lahan yang luas serta sumber daya manusia yang mayoritas bergerak di bidang pertanian. Sehingga wilayah ini dijadikan sebagai salah satu dari sembilan kabupaten lumbung padi dalam Program Operasi Pangan Riau Makmur. Desa Saik merupakan Desa dalam wilayah otonomi Kecamatan Kuantan Mudik Kabupaten Kuantan Singingi. Sebagian besar masyarakatnya beraktivitas dalam bidang tanaman pangan padi sejak tahun 1987, namun demikian produktivitas padi di daerah tersebut masih rendah dibuktikan belum berhasilnya Kecamatan Kuantan Mudik Berswaswmbada Pangan. Penelitian ini bertujuan untuk mengetahui bagaimana pengadaan sarana produksi dan keragaan usahatani padi sawah di Desa Saik Kecamatan Kuantan Mudik Kabupaten Kuantan Singingi. Hasil penelitian menunjukkan bahwa sarana produksi usahatani padi di Desa Saik tersedia sesuai dengan kebutuan petani, yang ditunjukkan dengan perolehan rerata skor 6 enam tepat $>75$ yaitu 81,04. Pada subsistem usahatani padi desa saik diketahui hasil produksi petani berupa beras dengan rata-rata jumlah produksi 4,033.65 kg/ha/musim tanam, petani memperoleh pendapatan kotor sebesar Rp 39,933,103.57/ha/ musim tanam, pendapatan bersih sebesar Rp 10,642,137.69 /ha/ musim tanam, dan rata-rata jumlah pendapatan keluarga yang diperoleh petani dari hasil usahatani padi sawah pada penelitian ini adalah Rp 25,126,273.10 /ha/ musim tanam. Melalui analisa pembiayaan dan 
analisis efisiensi diperoleh nilai RCR 1,36, yang menunjukkan bahwa usahatani padi sawah di Desa Saik layak untuk dikembangkan, diiringi usaha untuk meningkatkan efisiensi penggunaan saprodi dan tenaga kerja, sehingga dapat menekan biaya produksi dengan tetap mengupayakan produktifitas hasil yang tinggi.

Kata Kunci: Saprodi, padi sawah, Produktifitas.

\section{PENDAHULUAN}

Jumlah Penduduk Tahun 2015 di Provinsi Riau telah mencapai 6.344.402 jiwa, dan pada tahun 2017 berjumlah 6.657.911 jiwa (BPS Riau, 2017). Pertambahan jumlah penduduk setiap tahunnya harus diiringi dengan peningkatan berbagai sumber daya, termasuk sumber pangan. Ketersediaan bahan pangan yang dapat mencukupi kebutuhan seluruh penduduk di Provinsi Riau menjadi perhatian pemerintah dikarenakan ketahanan pangan dapat menjaga stabilitas pada suatu daerah.

Padi merupakan bahan pangan utama bagi sebagian besar penduduk Indonesia, termasuk di Provinsi Riau. Dari data BPS menunjukan bahwa luas panen padi di Provinsi Riau tahun 2013 sejumlah 118.518 hektar, namun pada tahun 2015 mengalami penurunan menjadi 107.546 hektar dengan produktivitas yang sama yaitu sebesar 36,63 kwintal per hektar. Kebutuhan beras Provinsi Riau untuk tahun 2017 adalah sebesar 677.095,6 ton, sementara produksi beras Riau baru mencapai 236.074,8 ton sehingga Riau masih kekurangan beras sebanyak 441.020,9 ton. Untuk memenuhi kebutuhan beras tersebut maka pemerintah perlu mendatangkan beras dari luar daerah seperti dari Sumatera Barat, Pulau Jawa, Sumatera Utara, dan sejumlah daerah lainnya

Program Operasi Pangan Riau Makmur (OPRM) yang di galakkan oleh Provinsi Riau dengan tujuan mendukung ketahanan pangan nasional dan secara bertahap mewujudkan swasembada pangan Riau dengan menjadikan 9 Kabupaten sebagai lumbung padi di Riau yakni; Indragiri Hilir, Rokan Hilir, Kuantan Singigi, Pelalawan, Kampar, Siak, Rokan Hulu, Bengkalis dan Kabupaten Indragiri Hulu. 
Kabupaten Kuantan Singingi mempunyai potensi pertanian yang sangat besar untuk dikembangkan, hal ini di dukung oleh ketersediaan lahan yang luas serta sumber daya manusia yang mayoritas bergerak di bidang pertanian. Kecamatan Kuantan Mudik, Kuantan Tengah, Benai, Kuantan Hilir, Cerenti, dan Singingi adalah enam kecamatan di kuantan singingi yang menjadi sentra pengembangan tanaman padi dalam rangka mewujudkan swasembada pangan.

Kabupaten Kuantan Singingi sebagai salah satu dari sembilan kabupaten yang dijadikan lumbung padi, dan ketiga terbesar dengan luas panen padi tahun 2015 sebesar 11.793 hektar, dengan luas panen pertama terdapat pada Kabupaten Indragiri Hilir ( 29.002 hektar) diikuti oleh Kabupaten Rokan Hilir (12.481 hektar). Pada tahun 2015 produksi padi di Kabupaten Kuantan Singingi adalah 52.823,64 ton padi sawah dan 10 ton padi ladang dengan luas panen 11.693 hektar padi sawah dan 10 hektar padi ladang. Berikut disajikan data mengenai luas panen dan produktivitas padi sawah di Kabupaten Kuantan Singingi tahun 2010 sampai tahun 2015.

Tabel 1. Data Luas Panen, Produksi dan Produktivitas Padi Sawah di Kabupaten Kuantan Singingi Tahun 2010 - 2015.

\begin{tabular}{lcccc}
\hline No & Tahun & Luas Lahan (ha) & Produksi (ton) & $\begin{array}{c}\text { Produktivitas } \\
\text { (ton/ha) }\end{array}$ \\
\hline 1 & 2010 & 10.228 & $43.488,17$ & 4.25 \\
2 & 2011 & 10.096 & $43.427,21$ & 4.30 \\
3 & 2012 & 10.980 & $47.396,38$ & 4.31 \\
4 & 2013 & 11.987 & $48.681,66$ & 4.06 \\
5 & 2014 & 11.177 & $51.986,09$ & 4.65 \\
6 & 2015 & 11.693 & $52.823,64$ & 4,52 \\
\hline
\end{tabular}

Sumber: BPS Kuantan Singingi, 2016

Rata-rata produktivitas komoditas padi sawah di Kabupaten Kuantan Singingi tahun 2015 adalah 4,52 ton per hektar, di atas ratarata produktivitas padi sawah di Provinsi Riau 3,66 ton per hektar dengan luas panen 107.546 hektar dan produksi 393.944 ton. Namun tingginya produktivitas komoitas padi di Kabupaten Kuantan Singingi masih rendah bila dibandingkan dengan produktivitas padi di negaranegara lain, dimana Mesir mampu memproduksi 9,9 ton per hektar, 
USA 7,44 ton per hektar, Jepang 6,65 ton per hektar sementara Indonesia 4,57 ton per hektar (FAOTAT 2007).

Faktor dominan penyebab rendahnya produktivitas tanaman pangan di Indonesia, Riau dan Kuansing adalah (a) Penerapan teknologi budidaya di lapangan yang masih rendah; (b)Tingkat kesuburan lahan yang terus menurun, (c) Eksplorasi potensi genetik tanaman yang masih belum optimal (Guedev S Kush, 2002). Tercapainya swasembada pangan, perlu dukungan dari berbagai sektor dan sub sektor, terutama berkaitan dengan prasarana dan sarana jaminan pasar, serta sejumlah kebijakan. Berdasarkan uraian diatas peneliti tertarik untuk melakukan analisis terhadap usaha tani padi sawah yang dilaksanakan di Desa Saik yang merupakan salah satu sentra penanaman padi yang berada dalam wilayah otonomi kecamatan kuantan mudik.

\section{METODE PENELITIAN}

\section{Tempat dan Waktu Penelitian}

Penelitian dilaksanakan di Desa Saik Kecamatan Kuantan Mudik Kabupaten Kuantan Singingi. Penelitian dilakukan selama 3 bulan yang meliputi kegiatan kegiatan Survei, pengumpulan data, tabulasi data, analisis data, dan penulisan laporan hasil penelitian.

\section{Metode Pengumpulan Data dan Pengambilan Responden}

Jenis data yang digunakan dalam penelitian adalah data primer dan data sekunder. Data primer diperoleh langsung dari petani dengan menggunakan daftar pertanyaan. Data yang diperoleh dari petani sampel meliputi (1) identitas responden, (2) pengadaan sarana produksi (jumlah, harga dan tempat beli), dan (3) keragaan usahatani (pengadaan input produksi, biaya produksi, produksi, pendapatan).

Data sekunder diperoleh dari lembaga /instansi yang terkait dalam penelitian ini, antara lain: Badan Pusat Statistik (BPS) Provinsi Riau, BPS Kabupaten Kuantan Singingi, dan Kantor Desa Saik Kecamatan Kuantan Mudik Kabupaten Kuantan Singingi. Data sekunder yang diperoleh meliputi: Profil Desa Saik, jumlah produksi padi dan luas 
lahan budidaya padi di Kabupaten Kuantan Singingi. Pengambilan data sekunder dilakukan dengan menggunakan data yang tersedia pada kantor atau dinas terkait, seperti kantor Kepala Desa Saik, kantor kecamatan Kuantan Mudik, dan BPS.

Populasi dalam penelitian ini adalah petani padi sawah yang tersebar di wilayah Desa Saik Kecamatan Kuantan Mudik Kabupaten Kuantan Singingi. Responden penelitian berjumlah 30 orang, yang dipilih menggunakan metode acak sederhana (simple Random Sampling). Hal ini dikarenakan sistem pengelolaan usahatani padi sawah di daerah penelitian, baik pada aspek pengadaan sarana produksi sampai dengan pemanenan yang dilakukan relatif sama.

\section{Metode Analisis Data}

Data yang telah dikumpulkan dan ditabulasikan dan dianalisis dengan menggunakan alat analisis sebagai berikut:

\section{Pengadaan Input Produksi Usahatani Padi}

Analisis pengadaan sarana produksi dilakukan dengan pendekatan 6 tepat yaitu: tepat waktu, tepat jenis, jumlah, mutu, harga dan tempat. Analisis yang dilakukan dengan menggunakan pendekatan (6) enam tepat menurut Soedijianto (1998) dalam menganalisis pengadaan sarana produksi usahatani padi dapat digunakan dengan memakai metode Tingkat Penerapan Teknologi (TPT) dengan mengunakan nilai skor; nilai skor yang telah digunakan adalah sebagai berikut:

1. Skor $<45=$ Tidak sesuai dengan kriteria 6 tepat

2. Skor 45-75= Kurang sesuai dengan kriteria 6 tepat

3. Skor $>75=$ Sesuai dengan kriteria 6 tepat

Angka skor

$5=$ Saprodi tidak tersedia saat dibutuhkan petani

$10=$ Saprodi tersedia tetapi kurang dari yang dibutuhkan petani

15 = Saprodi tersedia sesuai dengan dibutuhkan petani

\section{Analisis Usahatani Padi}

Analisis usahatani di antaranya berkaitan dengan teknik budidaya yang dilakukan petani, akan diidentifikasi besarnya biaya usahatani 
yang dikeluarkan, produksi, harga produk yang dihasilkan dan pendapatan yang diperoleh.

\section{a. Biaya}

Biaya produksi dalam usahatani padi adalah semua biaya yang dikeluarkan oleh petani selama satu musim produksi. Biaya produksi terdiri dari biaya tetap dan biaya variabel. Dihitung dengan menggunakan rumus umum menurut Hernanto (1991) sebagai berikut:

dimana:

$$
\mathrm{TC}=\mathrm{TVC}+\mathrm{TFC}
$$

$\mathrm{TC}=$ Total Cost $(\mathrm{Rp} / \mathrm{ha} / \mathrm{musim}$ tanam $)$

$\mathrm{TVC}=$ Total Variabel Cost $(\mathrm{Rp} / \mathrm{ha} / \mathrm{musim}$ tanam $)$

$\mathrm{TFC}=$ Total Fixed Cost $(\mathrm{Rp} / \mathrm{ha} /$ musim tanam $)$

Untuk kepentingan penelitian, maka rumusnya menjadi:

$$
\mathrm{TC}=\left\{\left(\mathrm{X}_{1} \cdot \mathrm{PX}_{1}+\mathrm{X}_{2} \cdot \mathrm{PX}_{2}+\mathrm{X}_{3} \cdot \mathrm{PX}_{3}+\mathrm{X}_{4} \cdot \mathrm{PX}_{4}+\mathrm{X}_{5} \cdot \mathrm{PX}_{5}+\mathrm{D}\right.\right.
$$

Keterangan:

$$
\begin{array}{ll}
\mathrm{TC} & =\text { Total cost }(\mathrm{Rp} / \mathrm{ha} / \mathrm{musim} \text { tanam }) \\
\mathrm{TFC} & =\text { Total fixed cost }(\mathrm{Rp} / \mathrm{ha} / \mathrm{musim} \text { tanam }) \\
\mathrm{TVC} & =\text { Total variabel cost }(\mathrm{Rp} / \mathrm{ha} / \text { musim tanam }) \\
\mathrm{X}_{1} & =\text { Benih }(\mathrm{kg} / \mathrm{ha} / \mathrm{musim} \text { tanam }) \\
\mathrm{PX}_{1} & =\text { Harga Benih }(\mathrm{Rp} / \mathrm{kg}) \\
\mathrm{X}_{2} & =\text { Pupuk }(\mathrm{kg} / \mathrm{ha} / \mathrm{musim} \text { tanam }) \\
\mathrm{PX}_{2} & =\text { Harga Pupuk }(\mathrm{Rp} / \mathrm{kg}) \\
\mathrm{X}_{3} & =\text { Pestisida }(\text { liter/ha/musim tanam }) \\
\mathrm{PX}_{3} & =\text { Harga Pestisida }(\mathrm{Rp} / \mathrm{liter}) \\
\mathrm{X}_{4} & =\text { Herbisida }(\mathrm{Liter} / \mathrm{ha} / \text { musim tanam }) \\
\mathrm{PX}_{4} & =\text { Harga Herbisida }(\mathrm{Rp} / \mathrm{liter}) \\
\mathrm{X}_{5} & =\text { Jumlah tenaga kerja }(\mathrm{HKP} / \mathrm{ha} / \mathrm{musim} \text { tanam}) \\
\mathrm{PX}_{5} & =\text { Upah tenaga kerja }(\mathrm{Rp} / \mathrm{HKP}) \\
\mathrm{D} & =\text { Penyusutan }(\mathrm{Rp} / \mathrm{ha} / \text { musim tanam })
\end{array}
$$

\section{b. Pendapatan}

Pendapatan dalam usahatani padi sawah terdiri dari pendapatan kotor dan pendapatan bersih. Pendapatan kotor yang diterima oleh 
petani dapat diperoleh dengan cara mengalikan antara jumlah produksi dengan harga yang berlaku, dihitung dengan menggunakan rumus:

$$
\mathrm{TR}=\mathrm{Y} . \mathrm{Py}
$$

Sedangkan untuk mengetahui pendapatan bersih usahatani padi diperoleh dengan menggunakan rumus umum menurut Soekartawi (1995), yaitu:

$$
\pi=\mathrm{TR}-\mathrm{TC}
$$

Dimana:

$\mathrm{TR}=$ Total Penerimaan $(\mathrm{Rp} / \mathrm{ha} / \mathrm{musim}$ tanam $)$

$\mathrm{Y} \quad=$ Jumlah Produksi ( $\mathrm{kg} / \mathrm{ha} /$ musim tanam)

Py $\quad=$ Harga Produksi $(\mathrm{Rp} / \mathrm{kg})$

$\pi \quad=$ Pendapatan Bersih (Rp/ha/musim tanam)

$\mathrm{TC}=$ Total Cost $(\mathrm{Rp} / \mathrm{ha} / \mathrm{musim}$ tanam $)$

\section{c. Biaya Penyusutan Alat}

Peralatan yang digunakan pada usahatani padi umumnya tidak habis dipakai untuk satu kali musim tanam (bisa digunakan berulangulang). Oleh karena itu, biaya peralatan yang dihitung sebagai komponen biaya produksi adalah nilai penyusutannya. Biaya penyusutan alat dalam usahatani dihitung dengan metode garis lurus (straight line method) menurut Sinuraya (1985):

$$
D=\frac{C-S V}{U L}
$$

Dimana:

$\mathrm{D}=$ Nilai Penyusutan Alat (Rp/unit/musim tanam)

$\mathrm{C} \quad=$ Harga Beli Alat (Rp/unit)

$\mathrm{SV}=$ Nilai Sisa Alat (Rp/unit) (diperoleh $20 \%$ dari nilai beli alat)

$\mathrm{UL}=$ Masa Pakai Alat (tahun)

\section{d. Efisiensi Usahatani}

selain pendapatan bersih yang dapat menunjukkan layak atau tidaknya suatu usahatani dapat juga dilihat dari nilai efisiensinya, yaitu 
dengan membandingkan antara pendapatan dengan total biaya produksi yang dikeluarkan. Efisiensi usahatani dianalisis Return Cost Ratio (RCR) dengan rumus menurut Hernanto (1991):

$$
\mathrm{RCR}=\frac{T R}{T C}
$$

Dimana:

RCR = Efisiensi Usahatani

$\mathrm{TR}=$ Pendapatan Kotor (Total Revenue) $(\mathrm{Rp} / \mathrm{ha} / \mathrm{musim}$ tanam)

$\mathrm{TC}=$ Total Biaya Produksi (Total Cost) (Rp/ha/musim tanam)

Dengan kriteria:

RCR $>1=$ Berarti usahatani padi menguntungkan

$\mathrm{RCR}<1 \quad=$ Berarti usahatani padi tidak menguntungkan

$\mathrm{RCR}=1 \quad=$ Berarti usahatani padiberada pada titik impas

\section{HASIL DAN PEMBAHASAN}

\section{Gambaran Wilayah Penelitian}

Desa Saik merupakan salah satu desa yang berada dalam wilayah otonomi Kecamatan Kuantan Mudik Kabupaten Kuantan Singingi dengan luas wilayah fasilitas umum Menurut Laporan Pendataan Profil Desa Saik Tahun 2015 seluas 4,77 Ha. Jumlah penduduk Desa Saik pada tahun 2015 berjumlah 968 jiwa, terdiri dari penduduk lakilaki sebanyak 510 orang $(51,72 \%)$, dan wanita 458 orang $(48,28 \%)$ dalam 224 Kepala Keluarga (KK).

Tingkat pendidikan penduduk dapat memberikan gambaran sikap penduduk terhadap pengadopsian dan penerapan teknologi maju untuk mendukung kegiatan yang diusahakan. Di Desa Saik tingkat pendidikan SLTP merupakan proporsi jumlah yang terbanyak yaitu 366 orang, sementara penduduk yang berada pada tingkat pendidikan Perguruan Tinggi masih tergolongan sedikit yaitu sebanyak 53 orang, mulai dari tamatan D1 sampai S1. Sebagai upaya dalam rangka meningkatkan pengetahuan dan kemampuan penduduk desa Saik maka perlu adanya dilaksanakan pelatihan dan pembinaan pada aspek keterampilan, seperti dengan mengadakan diklat pertanian atau 
magang ke daerah lain yang telah berhasil dalam usaha pertaniannya. Sehingga diharapkan pendidikan non formal tersebut secara langsung maupun tidak langsung dapat pula meningkatkan pergerakan ekonomi Desa Saik.

Jenis pekerjaan masyarakat Desa Saik cukup beragam, dengan profesi sebagian besar penduduk adalah petani, yakni sebanyak 526 orang. Sedangkan yang terkecil adalah buruh tani yaitu hanya sebanyak 4 orang. Kondisi ini mempunyai implikasi bahwa daerah tersebut berpotensi dikembangkan menjadi pusat pertanian khususnya tanaman pangan, sebab mayoritas penduduknya adalah petani yang memiliki lahan pertanian dan tentunya mereka sudah mempunyai kemampuan dalam bertani dari pengalaman yang telah mereka lakukan selama ini.

\section{Karakteristik Responden}

\section{Umur Responden}

BPS mengkelompokkan umur kedalam dua kategori yaitu umur produktif (15 sampai 64 tahun) dan umur tidak produktif ( $<15$ tahun dan >64 tahun). Berdasarkan pengelompokan umur tersebut maka diketahui sebagian besar petani padi di Desa Saik berada dalam kategori umur produktif dengan persentase 93,33\%, dimana rata-rata petani berumur 49,50 tahun. Mereka yang berada pada umur produktif cendrung memiliki semangat yang tinggi dengan tenaga yang lebih sehingga diharapkan memiliki motivasi yang tinggi untuk meningkatkan produktivitas kerja dan hasil usaha melalui pengembangan budidaya komoditas padi yang telah ditekuni dengan dukungan ketersediaan informasi dan teknologi dari PPL maupun media informasi yang saat ini lebih terbuka.

\section{Pendidikan}

Pendidikan masyarakat di suatu wilayah menjadi salah satu faktor pendukung tingkat keberhasilan pembangunan di wilayah tersebut, disamping adanya kesadaran dan motivasi yang tinggi. Baiknya kualitas pendidikan dapat dilihat melalui upaya masyarakat dalam peningkatan dan pemanfaatan potensi wilayah sebagai upaya meningkatkan taraf kehidupan bagi masyarakat tempatan. 
Biasanya seseorang yang berpendidikan tinggi lebih mampu untuk melihat peluang-peluang disekitarnya dan lebih terbuka terhadap adopsi inovasi teknologi bila dibandingkan dengan seseorang berpendidikan rendah yang cendrung berfikir secara tradisional. Adopsi inovasi dan teknologi di sini menjadi salah satu solusi dalam meningkatkan produktivitas usaha masyarakat sehingga menjadi lebih maju dan cepat berkembang.

Hasil penelitian menunjukkan bahwa sebagian besar petani padi sawah di Desa Saik berada pada kelompok pendidikan 1-9 tahun dengan rata-rata berada pada tingkat pendidikan SMP dengan persentase $86,66 \%$. Sementara petani yang melanjutkan pendidikan sampai ke taraf yang lebih tinggi hanya sebagian kecil dengan persentase 13,64 \%. Saat ini masyarakat Desa Saik sudah lebih terbuka terhadap pentingnya pendidikan bagi generasi muda dalam membangun desa, dilihat dari mulai banyaknya orang tua yang mendukung pendidikan anak-anak mereka sampai pada tingkat pendidikan perguruan tinggi. Sehingga diharapkan para generasi muda Desa Saik yang berpendidikan tinggi tersebut dapat menjadipenggerak pembangunan di daerahnya terutama dalam sektor pertanian.

\section{Pengalaman Berusahatani}

Usaha tani padi sawah merupakan mata pencaharian pokok sebagian besar masyarakat Desa Saik dan telah dilaksanakan secara turun temurun. Rata-rata petani di Desa Saik telah memiliki pengalaman usaha tani padi sawah selama 23 tahun. Petani responden penelitian yang memiliki penglaman usahatani termuda adalh selama 3 tahun dan tertua selama 60 tahun.

Semakin lama seseorang menggeluti suatu bidang usaha, maka semakin baik pemahamannya terhadap keberlangsungan usaha tersebut. Begitu hanya dengan usaha tani padi sawah yang digeluti sebagian besar masyarakat Desa Saik. Setiap kendala dan keberhasilan yang mereka capai dalam tahun-tahun mereka menggeleti usaha tani padi sawah menjadi pengalaman dan pembelajaran yang berharga sebagai modal dalam meningkatkan produktivitas hasil dan pendapatan dari kegiatan usaha tani yang ditekuni.

\section{Jumlah Tanggungan Keluarga}


Tanggungan keluarga adalah semua orang yang tinggal dalam satu rumah dimana biaya dan kebutuhan hidup lainnya ditanggung oleh kepala keluarga. Besar kecilnya jumlah tanggungan keluarga memberikan pengaruh terhadap perekonomian suatu rumah tangga, termasuk jumlah anggota keluarga yang produktif maupun yang tidak produktif. Banyaknya anggota keluarga yang berada pada umur produktif dapat menunjang perekonomian keluarga yang turut serta memberikan sumbangan pendapatan rumah tangga.

Hasil penelitian menunjukkan bahwa rata-rata petani padi desa saik memiliki tanggungan keluarga sebanyak 5 orang, dengan jumlah tanggungan keluarga terkecil sebanyak 1 orang dan tanggungan keluarga dengan jumlah terbesar sebanyak 8 orang. Bagi rumah tangga yang aktifitas ekonominya berada pada bidang pertanian, keberadaan anggota keluarga yang berada pada umur produktif dapat menjadi sumber tenaga kerja yang utama dalam menunjang kegiatan usaha tani, sehingga biaya tenaga kerja yang seharusnya dikeluarkan oleh tenaga kerja luar keluarga dapat ditekan.

\section{Subsistem Pengadaan Sarana Produksi Usahatani Padi Sawah}

Ketersediaan dan kemudahan dalam mengakses sarana produksi, seperti benih, pupuk, pestisida, serta alat dan mesin pertanian menjadi hal penting yang harus diperhatikan untuk mendukung keberhasilan pengelolaan usahatani. Baiknya sistem pengadaan sarana produksi dapat dilihat dari enam aspek yang biasa disebut dengan kaidah 6 tepat yaitu tersedia tepat waktu, tempat, jumlah, jenis, mutu dan harga. Mengenai penyediaan sarana produksi dalam mendukung usahatani padi di Desa Saik disajikan pada tabel 2 berikut.

Tabel 2. Ketersediaan Sarana Produksi pada Usahatani Padi di Desa Saik Kecamatan Kuantan Mudik Kabupaten Kuantan Singingi.

\begin{tabular}{|c|l|c|c|c|c|c|c|c|}
\hline No & $\begin{array}{c}\text { Sarana } \\
\text { Produksi }\end{array}$ & Waktu & Tempat & Jumlah & Jenis & Mutu & Harga & $\begin{array}{c}\text { Rata-rata } \\
\text { Skor }\end{array}$ \\
\hline 1 & Benih & 15.00 & 15.00 & 15.00 & 12.00 & 12.17 & 15.00 & 84.17 \\
\hline 2 & Pupuk & 11.00 & 10.33 & 12.33 & 15.00 & 14.33 & 9.00 & 72.00 \\
\hline 3 & Pestisida & 12.17 & 13.00 & 15.00 & 15.00 & 15.00 & 9.83 & 80.00 \\
\hline
\end{tabular}




\begin{tabular}{|c|c|c|c|c|c|c|c|}
\hline Peralatan & 13.67 & 14.33 & 15.00 & 15.00 & 15.00 & 15.00 & 88.00 \\
\hline Rata-rata & 12.96 & 13.17 & 14.33 & 14.25 & 14.13 & 12.21 & 81.04 \\
\hline
\end{tabular}

Keterangan :

Skor $<45 \quad$ : Saprodi tidak tersedia saat dibutuhkan petani

Skor $45-75$ : Saprodi tersedia tetapi kurang dari kebutuhan petani

Skor $>75$ : Saprodi tersedia sesuai dengan kebutuhan petani

Berdasarkan tabel 2 diketahui perolehan rata-rata skor penyediaan saprodi usahatani padi bagi petani Desa Saik memperoleh skor 81,04 yang menunjukkan bahwa secara keseluruhan penyediaan sarana produksi tersedia sesuai dengan kebutuan petani. Dari keempat jenis saprodi diatas, saprodi jenis benih, pestisida dan peralatan pertanian memperoleh nilai rata-rata skor $>75$ yang menunjukkan bahwa ketiga jenis sarana produksi tersebut tersedia sesuai dengan kebutuhan petani. Sementara sarana produksi pupuk memperoleh nilai rata-rata skor $<75$ yaitu sebesar 72, yang menunjukkan bahwa pupuk tersedia tetapi kurang dari kebutuhan petani.

Petani memperoleh sarana produksi seperti pupuk, pestisida dan peralatan pertanian dengan cara membeli di toko penjual sarana produksi yang terdapat di Kecamatan Kuantan Mudik. Sementara benih padi diperoleh petani dari hasil panen sebelumnya. Dari ke enam aspek enam tepat dalam penyediaan sarana produksi usahatani padi di Desa Saik, harga merupakan komponen dengan perolehan rata-rata skor terkecil, hal ini dikarenakan kurangnya kemampuan petani dari aspek permodalan dalam menjalankan usaha taninya.

\section{Subsistem Usaha Tani Padi Sawah}

\section{Penggunaan Input Produksi}

Input produksi dalam setiap kegiatan usaha tani menjadi salah satu faktor penentu barjalannya kegiatan usahatani. Ketersediaan sarana dan input produksi yang sesuai dengan kebutuhan usahatani dapat mendukung petani dalam memperoleh produktivitas hasil yang memuaskan baik secara kuantitas maupun kualitas. Adapun input 
produksi yang digunakan oleh petani padi sawah di Desa Saik disajikan pada tabel berikut.

Tabel 3. Distribusi Jumlah Penggunaan Input Produksi pada Usahatani Padi di Desa Saik Kecamatan Kuantan Mudik Kabupaten Kuantan Singingi /ha/musim tanam.

\begin{tabular}{|l|l|r|r|}
\hline No & \multicolumn{1}{|c|}{$\begin{array}{c}\text { Jenis Input } \\
\text { Produksi }\end{array}$} & $\begin{array}{c}\text { Jumlah } \\
\text { Penggunaan }\end{array}$ & \multicolumn{1}{|c|}{ Rekomendasi* } \\
\hline 1. & Benih $(\mathrm{kg})$ & 59.67 & $10-20 \mathrm{~kg}$ \\
\hline 2. & Pupuk (kg) & & $300 \mathrm{~kg}$ \\
\hline & a. Urea & 203.71 & $200 \mathrm{ton}$ \\
\hline & b. NPK & 293.81 & $100 \mathrm{~kg} \mathrm{Sp}-36,100 \mathrm{~kg} \mathrm{KCl}$ \\
\hline & c. Kompos & 142.41 & \\
\hline 3. & Insektisida (liter) & 5.75 & \\
\hline 4. & Herbisida (liter) & 13.40 & \\
\hline
\end{tabular}

*) Rekomendasi dari BBPTP Balitbang Kementan

\section{Benih}

Pemilihan benih yang tepat dan sesuai dengan kondisi areal usahatani menjadi hal penting yang harus diperhatikan, agar petani dapat memperoleh produktivitas hasil yang optimal. Berdasarkan data di lapangan diketahui terdapat empat varietas padi yang digunakan oleh petani padi sawah Desa Saik, diantaranya Bimas Malaysia, PB 42, Padi Kuniang dan Sigam Putih, dimana sebagian besar petani menggunakan varietas Bimas Malaysia.

Benih padi yang digunakan dalam kegiatan usaha tani padi sawah tersebut diperoleh petani dari penyimpanan hasil produksi musim tanam sebelumnya, dengan pertimbangan bahwa hasil panen padi musim tanam sebelumnya tersebut masih cukup baik untuk dijadikan benih musim tanam selanjutnya, benih mudah diperoleh dan petani tidak perlu mengeluarkan biaya untuk membeli benih musim tanam berikutnya. Penyuluh pertanian lapangan Desa Saik turut menyediakan benih padi hibrida untuk mempermudah petani dalam memperoleh benih, namun demikian para petani lebih memilih menggunakan benih dari hasil panen sebelumnya. Rata-rata petani padi sawah desa saik menggunakan 59,67 kg benih per hektar lahan untuk satu musim tanam. Jumlah tersebut jauh lebih besar dari 
penggunaan benih yang telah direkomendasikan, dimana rekomendasi penggunaan benih padi hibrida sebanyak 10 -20 kg per hektar (BBPTP Balitbang Kementan), sementara penggunaan benih dengan spesifik lokal adalah sebanyak $40 \mathrm{kag} / \mathrm{ha}$ (BPTP Perhentian Marpoyan Pekanbaru).

\section{Pupuk}

Pupuk menjadi salah satu unsur penting yang mendukung proses pertumbuhan tanaman hingga dapat memberikan produktivitas hasil yang optimal. Pemupukan dilakukan karena unsur hara yang tersedia pada tanah belum dapat memenuhi kebutuhan tanaman. Pupuk yang digunakan petani padi sawah di desa Saik dalam satu kali musim tanam terdiri dari pupuk organik dan anorganik dengan rata-rata dosis aplikasi pupuk urea 203,71 kg per hektar, pupuk NPK $293.8 \mathrm{~kg}$ per hektar, dan pupuk organik kompos $142.41 \mathrm{~kg}$ per hektar. Pupuk-pupuk tersebut diperoleh petani dengan membeli pada kios pertanian yang berada di Kecamatan Kuantan Mudik.

Tanaman padi membutuhkan berbagai unsur hara untuk dapat memberikan produktivitas hasil yang optimal. Unsur hara tersebut terdiri dari unsur hara makro yang banyak tersedia pada jenis pupuk organik, dan unsur hara mikro yang dapat diperoleh tanaman melalui aplikasi jenis pupuk anorganik. Dalam usahatani padi, jenis pupuk yang biasa digunakan oleh petani adalah pupuk Urea, TSP dan $\mathrm{KCl}$ dengan rekomendasi aplikasi pada penggunaan jenis benih padi hibrida untuk satu hektar lahan per satu musim tanam adalah $300 \mathrm{~kg}$ pupuk urea, $100 \mathrm{~kg}$ pupuk Sp-36, $100 \mathrm{~kg}$ pupuk $\mathrm{KCl}$ dan 200 ton pupuk kompos (BBPTP Balitbang Kementan). Sementara rekomendasi dosis pemupukan untuk tanaman padi spesifik lokal dalam satu kali musim tanam adalah adalah Urea $150 \mathrm{~kg} / \mathrm{ha}$, TSP 150 $\mathrm{kg} / \mathrm{ha}$ dan $\mathrm{KCl} 125 \mathrm{~kg} / \mathrm{ha}$ (BPTP Padang Marpoyan).

Hasil penelitian menunjukkan bahwa dosis pemupukan yang diterapkan oleh petani padi sawah di Desa Saik hampir mendekati dengan dosis pemupukan yang direkomendasikan oleh Balai Penelitian Tanaman Pangan, namun demikian terdapat perbedaan jenis pupuk yang digunakan. Dimana petani padi sawah di Desa Saik mengaplikasikan jenis pupuk Urea, NPK, dan Kompos untuk 
memunuhi kebutuhan hara tanaman padi yang di budidayakan. Petani tidak menggunak pupuk TSP dan KCL dikarenakan kedua jenis pupuk tersebut kurang tersedia sesuai dengan kebutuhan petani dengan harganya cukup mahal, sehingga petani memilih menggunakan pupuk Urea dan NPK sebagai sumber pemenuhan unsur hara Phospate dan kalsium bagi tanaman padi, karena pupuk tersebut merupakan jenis pupuk yang tersedia dan mendapatkan subsidi dari pemerintah. Selain itu petani juga memberikan pupuk kompos pada areal persawahan, dilihat dari kuantiti jumlah dosis pupuk kompos yang diaplikasikan kurang dari yang direkomendasikan BBPTP Balitbang Kementan, dikarenakan setelah panen petani setempat biasa melepaskan ternak kerbau mereka diareal persawahan. Sehingga sisa jerami pasca panen dimakan ternak dan kotoran kerbau menjadi sumber pupuk organic bagi musim tanam selanjutnya.

\section{Pestisida}

Keberadaan hama babi, burung, keong mas, dan walang sangit menjadi kendala petani dalam menjalankan budidaya padi sawah di Desa Saik, karena hama-hama tersebut dapat menurunkan produktifitas hasil bahkan menyebabkan petani gagal panen. Untuk mengatasi permasalahan tersebut petani mengaplikasikan insektisida jenis Decis m 45 dengan rata-rata dosis aplikasi 5,75 liter per hektar lahan. Sementara untuk mengendalikan gulma di areal persawahan petani menggunakan herbisida jenis roundup dan DMA 6 dengan jumlah dosis aplikasi 13,40 liter per hektar lahan untuk kedua jenis herbisida tersebut.

\section{Penggunaan Tenaga Kerja}

Curahan tenaga kerja meliputi seluruh rangkaian kegiatan usahatani mulai dari pengolahan lahan sampai pemanenan yang dinyatakan dalam satuan Hari Kerja Pria (HKP), dengan jam kerja selama 8 jam dengan upah Rp 80.000 per HKP. Adapun rata-rata penggunaan tenaga kerja pada usaha tani padi sawah di Desa Saik disajikan pada table berikut. 
Tabel 4. Jumlah Penggunaan Tenaga Kerja Berdasarkan Tahapan Kerja pada Usahatani Padi di Desa Saik Kecamatan Kuantan Mudik Kabupaten Kuantan Singingi /ha/musim tanam.

\begin{tabular}{|r|l|r|r|r|}
\hline No & \multicolumn{1}{|c|}{ Tahapan Kerja } & \multicolumn{1}{c|}{$\begin{array}{c}\text { TKDK } \\
\text { (HKP) }\end{array}$} & $\begin{array}{c}\text { TKLK } \\
\text { (HKP) }\end{array}$ & $\begin{array}{c}\text { Jumlah } \\
(\text { HKP })\end{array}$ \\
\hline 1. & Pengolahan Lahan I & 40.59 & 47.65 & 88.24 \\
\hline 2. & Pengolahan Lahan II & 27.25 & 26.52 & 53.77 \\
\hline 3. & Penyemaian & 7.35 & - & 7.35 \\
\hline 4. & Penanaman & 19.19 & 1 & 30.35 \\
\hline 5. & Penyisipan & 3.27 & - & 3.38 \\
\hline 6. & Penyiangan I & 9.43 & 9 & 8.45 \\
\hline 7. & Penyiangan II & 8.73 & 8.42 & 7.15 \\
\hline 8. & Pemupukan I & 8.22 & 0.33 & 8.55 \\
\hline 9. & Pemupukan II & 7.99 & - & 7.99 \\
\hline 10. & PHPT I & 7.04 & - & 7.04 \\
\hline 11. & PHPT II & 7.04 & - & 7.04 \\
\hline 12. & Pemanenan & 25.34 & 26.63 & 51.98 \\
\hline & Jumlah & 171.45 & 129.83 & 301.29 \\
\hline
\end{tabular}

Hasil penelitian menunjukkan bahwa petani menggunakan tenaga kerja yang berasal dari dalam dan luar keluarga untuk menyelesaikan setiap tahapan kerja pada usahatani padi sawah. Penggunaan tenaga kerja dalam keluarga (TKDK) meliputi seluruh tahapan kerja dalam usahatani, sementara untuk tenaga kerja luar keluarga (TKLK) curahan waktu kerjanya hanya pada tahapan kerja yang memerlukan tenaga kerja yang cukup besar dan harus segera diselesaikan seperti pengolahan lahan, penanaman, penyiangan, pemupukan dan pemanenan.

Jumlah rata-rata tenagakerja yang digunakan petani untuk seluruh tahapan kerja adalah 302 HKP per hektar lahan, yang terdiri dari 172 HKP TKDK dan 130 HKP TKLK. Curahan waktu kerja terbanyak berada pada tahapan kerja pengolahan tanah I dengan total penggunaan tenaga kerja $89 \mathrm{HKP}$, yang terdiri dari 41 HKP TKDK dan 48 HKP TKLK. Sementara curahan waktu kerja terkecil berada pada tahapan kerja penyisipan dengan total curahan waktu kerja 
sebesar 4 HKP yang sumber tenaga kerjanya hanya berasal dari TKDK.

\section{Pembiayaan Usahatani}

Komponen Pembiayaan menjadi hal yang mendasar dalam suatu kegiatan usahatani. Besar kecilnya sekala usaha mempengaruhi jumlah modal kerja yang digunakan. Pembiayaan menjadi hal yang penting untuk diperhatikan bagi setiap pelaku usaha, karena berdasarkan komponen pembiayaan tersebut pelaku usaha dapat mengambil keputusan terkait usaha yang mereka jalani. Berikut disajikan mengenai komponen pembiayaan dalam usahatani padi sawah yang dilaksanakan petani di Desa Saik.

Tabel 5.Komponen Pembiayaan, Pendapatan, dan Efisiensi Usahatani Padi di Desa Saik Kecamatan Kuantan Mudik Kabupaten Kuantan Singingi /ha/musim tanam.

\begin{tabular}{|r|l|r|r|r|r|}
\hline No & \multicolumn{1}{|c|}{ Uraian } & Jumlah & $\begin{array}{c}\text { Harga/satuan } \\
(\mathrm{Rp})\end{array}$ & Total (Rp) & $\begin{array}{c}\text { Persenta } \\
\text { se (\%) }\end{array}$ \\
\hline $\mathbf{1}$ & Biaya variabel (TV) & & & & \\
\hline & benih (Kg) & 59.67 & $12,466.67$ & $743,923.60$ & 2.54 \\
\hline & Pupuk & & & & \\
\hline & Urea & 293.71 & $5,000.00$ & $1,018,551.59$ & 3.48 \\
\hline & NPK & 142.41 & $8,000.00$ & $2,350,476.19$ & 8.02 \\
\hline & Kompos & 5.75 & $38,000.00$ & $218,679.25$ & 0.75 \\
\hline & Insektisida (Liter) & 13.40 & $43,000.00$ & $576,037.74$ & 1.97 \\
\hline & Herbisida (Liter) & & & $\mathbf{5 , 1 6 4 , 0 1 1 . 2 1}$ & 17.63 \\
\hline & Total & & & & \\
\hline $\mathbf{2}$ & Biaya Tetap (TF) & & & & \\
\hline & Tenaga Kerja & 171.45 & $80,000.00$ & $13,716,190.48$ & 46.83 \\
\hline & TKDK (HKP) & 129.83 & $80,000.00$ & $10,386,742.86$ & 35.46 \\
\hline & TKLK (HKP) & & & $24,021.33$ & 0.08 \\
\hline & Penyusutan alat & & & $\mathbf{2 4 , 1 2 6 , 9 5 4 . 6 7}$ & 82.37 \\
\hline & Total & & & & \\
\hline $\mathbf{3}$ & Total Biaya (TC) & & & $\mathbf{2 9 , 2 9 0 , 9 6 5 . 8 8}$ & 0.00 \\
\hline & TC= TV+TF & & & & \\
\hline $\mathbf{4}$ & Produksi (Q) (Kg) & $\mathbf{4 , 0 3 3 . 6 5}$ & & & \\
\hline $\mathbf{5}$ & Harga Jual (P) & & $\mathbf{9 , 9 0 0 . 0 0}$ & & \\
\hline $\mathbf{6}$ & Pendapatan & & & & \\
\hline
\end{tabular}




\begin{tabular}{|l|l|r|}
\cline { 2 - 3 } & Pendapatan Kotor (TR= Q x P) & $39,933,103.57$ \\
\hline & Pendapatan Bersih $(\pi=$ TR - TC) & $10,642,137.69$ \\
\hline & Pendapatan Keluarga & $25,126,273.10$ \\
\hline $\mathbf{7}$ & Efisiensi Usaha (TR / TC) & $\mathbf{1 . 3 6}$ \\
\hline
\end{tabular}

Sumber: Data Olahan, 2018

Berdasarkan hasil penelitin yang ditunjukkan pada Tabel 5 terlihat bahwa rata-rata jumlah biaya produksi usahatani padi dilokasi penelitian sebesar Rp 29,290.965,88/ha/musim tanam. Dari total biaya produksi tersebut, komponen pembiayaan upah tenaga kerja dalam keluarga merupakan biaya terbesar yaitu Rp 13,716,190.48 (46,83\%) dari total biaya produksi. Biaya produksi terendah adalah biaya penyusutan alat-alat pertanian yaitu hanya sebesar Rp 24,021.33 $(0,08 \%)$ dari seluruh total biaya produksi usahatani padi.

\section{Produksi Usahatani Padi}

Produksi usahatani padi dalam penelitian ini adalah beras yang diukur dalam satuan $\mathrm{kg} / \mathrm{ha} /$ musim tanam. Rata-rata jumlah produksi yang dihasilkan petani sebanyak 4,033.65 kg/ha/musim tanam. Dari hasil panen yang diperoleh dalam satu musim tanam, petani membagi hasil produksinya untuk persediaan benih musim tanam selanjutnya, beras konsumsi dan sebagian lagi dijual kepada pedagang pengumpul.

\section{Pendapatan dan Efisiensi Usahatani Padi}

Pendapatan yang diperoleh petani dari usahatani padi sawah terdiri dari pendapatan kotor, pendapatan bersih dan pendapatan keluarga. Pendapatan kotor (TR) diperoleh dari perkalian antara jumlah produksi dengan harga produk yang berlaku di daerah penelitian. Besarnya tingkat pendapatan yang diterima petani akan tergantung kepada besarnya produksi serta harga jual dan biaya produksi yang dikeluarkan dalam berusahatani padi.

Pada penelitian ini hasil produksi petani berupa beras dengan ratarata jumlah produksi $4,033.65 \mathrm{~kg} / \mathrm{ha} /$ musim tanam, dengan harga beras di tingkat petani pada saat penelitian sebesar Rp 9.900 maka petani memperoleh pendapatan kotor sebesar Rp 39,933,103.57/ha/ musim tanam. Pendapatan bersih petani padi diperoleh dari pendapatan kotor yang diterima dikurangi dengan total biaya produksi, semakin tinggi jumlah produksi yang dihasilkan maka akan semakin 
tinggi pendapatan dari usahatani padi tersebut dengan asumsi biaya produksi dan harga tetap. Melalui perhitungan komponen pembiayaan yang dikeluarkan petani untuk memenuhi sarana produksi usahataninya, maka diketahui bahwa rata-rata petani memperoleh pendapatan bersih sebesar Rp 10,642,137.69 /ha/ musim tanam.

Pendapatan keluarga pada penelitian ini adalah jumlah dari komponen yang dapat dinikmati petani melalui hasil usahanya, adapun komponen tersebut terdiri dari jumlah penerimaan (pendapatan bersih), nilai penyusutan, upah TKDK dan nilai benih yang dikeluarkan dari hasil produksi musim tanam sebelumnya. Adapun rata-rata jumlah pendapatan keluarga yang diperoleh petani dari hasil usahatani padi sawah pada penelitian ini adalah $\operatorname{Rp} 25,126,273.10$ /ha/ musim tanam.

Melalui analisa pembiayaan dan analisis efisiensi usahatani yang diukur dengan Return Cost Ratio (RCR), maka dapat diketahui kelayakan usahatani padi sawah yang dijalankan petani di Desa Saik Kecamatan Kuantan Mudik Kabupaten Kuantan Singingi. Nilai RCR yang diperoleh yaitu sebesar 1,36, yang berarti bahwa setiap Rp 1 biaya yang dialokasikan untuk usahatani padi akan menghasilkan pendapatan kotor sebesar Rp 1,36 atau pendapatan bersih sebesar Rp 0,36 . Hal tersebut menunjukkan bahwa usahatani padi sawah di daerah penelitian layak untuk dikembangkan, namun demikian petani harus lebih meningkatkan efisiensi penggunaan saprodi dan tenaga kerja, sehingga dapat menekan biaya produksi dengan tetap mengupayakan produktifitas hasil yang tinggi. Hal tersebut dapat dicapai petani melalui dukungan berbagai pihak, salahsatunya tenaga penyuluh pertanian lapangan.

\section{KESIMPULAN}

1. Sarana produksi usahatani padi di Desa Saik tersedia sesuai dengan kebutuan petani, yang ditunjukkan dengan perolehan rerata skor 6 enam tepat $>75$ yaitu 81,04.

2. Pada subsistem usahatani padi desa saik diketahui hasil produksi petani berupa beras dengan rata-rata jumlah produksi 4,033.65 $\mathrm{kg} / \mathrm{ha} /$ musim tanam, petani memperoleh pendapatan kotor sebesar 
Rp 39,933,103.57/ha/ musim tanam, pendapatan bersih sebesar Rp 10,642,137.69/ha/ musim tanam, dan rata-rata jumlah pendapatan keluarga yang diperoleh petani dari hasil usahatani padi sawah pada penelitian ini adalah Rp 25,126,273.10 /ha/ musim tanam. Melalui analisa pembiayaan dan analisis efisiensi diperoleh nilai RCR 1,36, yang menunjukkan bahwa usahatani padi sawah di Desa Saik layak untuk dikembangkan, diiringi usaha untuk meningkatkan efisiensi penggunaan saprodi dan tenaga kerja, sehingga dapat menekan biaya produksi dengan tetap mengupayakan produktifitas hasil yang tinggi.

\section{DAFTAR PUSTAKA}

BPS Riau, 2017

FAO TAT. 2007. Rice In Human Nutrition

Friyanto, S. 2001 Analisis Penerapan Intensifikasi Usahatani Padi Sawah Pasca Krisis Ekonomi (Kasus di Kabupaten Subang, Jawa Barat) Makalah Badan Penelitian dan Pengembangan Pertanian, Departemen Pertanian RI.

Hernanto, F. 1996. Ilmu Usaha Tani. Penerbar Swadaya, Jakarta.

Reginawaty, 1999. Padi. BPTP Sukamandi Subang, Jawa Barat, Bandung

Sinuraya, R. 1985. Pengantar Ilmu Akuntansi II. Fakultas Ekonomi. Universitas Sumatra Utara. Medan

Soekartawi. 1995. Prinsip Dasar Ekonomi Pertanian Teori dan Aplikasi. Raja Grafindo. Jakarta

Soedijianto. 1998. Program Penyuluhan Pertanian. Universitas Terbuka. Depdikbud. Jakarta.

Subiakto, 1996. Manajemen Agribisnis. Kansius, Jakarta

Suparyono, A.S., 1993. Padi. Penebar Swadaya Jakarta.

Yasin, F.A.Z. dan M. Ahmad. 1996. Usahatani Kecil Agribisnis dan Kelembagaan, UNRI Press, Pekanbaru. 
Yasin, F.A.Z., Saipul Bahri, Ahmad Rifai' Djaimi dan Azharuddin. 2002 Analisis Struktur Biaya dan Ekonomi Usaha Padi Sawah Atas Kebijakan Harga Pupuk di Kabupaten Kampar, Jurnal Dinamika Pertanian, 17 (1): 128-139. 